\title{
George Harris and the Comparative Legal Background of the First English Translation of Justinian's Institutes
}

\author{
ŁUKASZ JAN KORPOROWICZ
}

\section{Introduction}

Modern scholarship on Roman law, as well as any other legal history discipline, emphasises the importance of the editions and translations of the sources. This trend, however, is not new; it is well observed since at least the nineteenth century. Instances include the discovery of Gaius's palimpsest, the standard editions of the Corpus iuris civilis as well as the Corpus iuris canonici, and the editing and publishing of old English yearbooks and law reports. The decreasing knowledge of Latin, a primary factor in initiating the translations, can be dated back at least one hundred years earlier, into the eighteenth century. ${ }^{1}$ The growth of the importance of national laws and languages also helped to render Latin increasingly out-of-date. For this reason, it became obvious that the approach to Roman law sources had to change. Translations became a necessary tool for studying old law. The English outcome was the translation of Justinian's Institutes prepared by George Harris in the mideighteenth century. His work is important for several reasons. First of all, it was the first proper English translation of any part of Justinian's codification. Also, Harris did not limit his work only to preparing an English version of the ancient textbook. He equipped it with many

${ }^{1}$ Concerning non-legal sources, this can be traced back even a century or two earlier. Since at least the mid-sixteenth century it is possible to observe constant efforts to render ancient classical works into English. Some of them were rather close to a paraphrase, but some others were direct translations; see J. E. Sandys, A History of Classical Scholarship, 3 vols. (Cambridge, 1903-8), vol. II, 239-43. It is interesting, however, that among these works are no legal texts. One of the early attempts to translate a Latin legal text into English is Clement Barksdale's translation of De iure belli ac pacis authored by Hugo Grotius; see M. Barducci, Hugo Grotius and the Century of Revolution, 1613-1718: Transnational Reception in English Political Thought (Oxford, 2017), 99-101. 
scholarly notes, especially important due to its many references to English legal tradition. For this reason, Harris's work can be considered as a valuable example of an early comparative legal study.

\section{George Harris}

George Harris was born in Westminster in $1721 .^{2}$ It seems that he spent part of his childhood in Wales with his father, John Harris, who was appointed bishop of Llandaff in $1729 .^{3}$ Shortly before his father's death, in June 1738, George was matriculated at Oriel College, Oxford. In 1745 he obtained the degree of Bachelor in Civil Law and five years later a doctoral degree. ${ }^{4}$ Later the same year, on 23 October, Harris was admitted to the College of Advocates, and he began a legal practice. During his long-term membership, he performed many administrative functions: register (1763-4), librarian (1765-6) and treasurer (1767-70; 1781-2). ${ }^{5}$ In addition, he was involved in the administrative and judicial organisation of many dioceses. It was noted in his obituary published in The Annual Register that Harris was chancellor of the dioceses of Durham, Hereford and Llandaff as well as the commissioner of Essex, Hertfordshire and Surrey. ${ }^{6}$ This list can be supplemented with two more chancellorships in Bangor and Winchester. ${ }^{7}$ It seems that most of these appointments were held by Harris almost until his death. ${ }^{8}$

It is possible to locate some traces of Harris's practice as advocate. Archival investigation indicates the survival of several legal opinions presented by Harris. Most of them concern ecclesiastical matters, primarily regarding staffing of offices. Lambeth Palace Library possesses

2 See e.g. T. A. B. Corley, 'Harris, George (bap. 1721, d. 1796)', in Oxford Dictionary of National Biography (Oxford, 2004), available at www.oxforddnb.com/view/10.1093/ref: odnb/9780198614128.001.0001/odnb-9780198614128-e-12386? rskey=lHXxYn\&result=2.

${ }^{3}$ L. Thomas, 'Harris, John (1680-1738), Bishop of Llandaff, in Dictionary of Welsh Biography, available at https://biography.wales/article/s-HARR-JOH-1680.

${ }^{4}$ C. L. Shadwell, Registrum Orielense: An Account of the Members of Oriel College, 2 vols. (London, 1893-1902), vol. II, 94.

5 G. D. Squibb, Doctors' Commons: History of the College of Advocates and Doctors of Law (Oxford, 1977), 192.

6 The Annual Register for the Year 1796. Chronicle, 2nd edn (London, 1807), 14-15.

7 'Chancellors of the Dioceses of Bangor', Old Wales, 1 (1905), 218-19.

${ }^{8}$ Ibid. 
three such opinions dated 1770/1, 1784 and 1787. ${ }^{9}$ Another two opinions are held by the local archives in Yorkshire (1764) and Devon (1780). ${ }^{10}$

Like many other eighteenth-century civilians, Harris was also involved in judicial work. For many years he was a judge of the Prerogative Court of Canterbury. Through the press testamentary reports, it is possible to see that Harris was performing judicial duties as early as March 1759, when he proved the will and codicils of Henry Hawley. ${ }^{11}$ He was still acting as a judge in 1790 when he proved the will of the well-known eccentric John Elwes. ${ }^{12}$

Besides the Prerogative Court, Harris was also acting as a judge while he was holding the diocesan offices. While he was a commissioner of Surrey, then part of the diocese of Winchester, Harris was engaged in an unusual case. At the time, the bishop of Winchester was visitor of Magdalen College, Oxford. He exercised his powers through the commissioner. In 1769 Harris was presiding over a hearing in a case regarding the deprivation of Ambrose Kent of his Doctor of Divinity degree and fellowship at Magdalen College. It seems that these hearings were partly informal since they were taking place in such different locations as Harris's chambers, the common-hall of Doctors' Commons and the bishop's home in Chelsea. ${ }^{13}$

Harris's judicial activity on behalf of the Winchester diocese was perpetuated by John Wentworth. By the end of the eighteenth century, this barrister and member of the Inner Temple published several volumes regarding judicial proceedings. The matters discussed were illustrated with actual examples from practice. During the analysis of the writ of prohibition, Wentworth included in his book a motion to grant a writ, the writ itself signed by George III, as well as Harris's declaration of admitting the writ, all concerning the 1777 case. $^{14}$

Kent's was not the only university case in which Harris was involved. In 1793 Jesus College, Cambridge sent a request to the civilian for an

${ }^{9}$ Lambeth Palace Library (LPL), MS 3416, fos. $10-12 \mathrm{v}, 20 \mathrm{v}-22 \mathrm{v}, 30 \mathrm{v}-35 \mathrm{v}$ and $39 \mathrm{v}-40$.

${ }^{10}$ East Riding of Yorkshire Archives and Local Studies Service, DDRI/27/17; Devon Archives and Local Studies Service, 2994A/PW 58.

11 The Annual Register, or a View of the History, Politics, and Literature, of the Year 1759 (London, 1760), 348-51.

12 The Lady's Magazine, March 1790, 129.

${ }^{13}$ For more about the case, see The Conduct of the Right Reverend the Lord Bishop of Winchester, as Visitor of St Mary Magdalen College, Oxford, Fully Stated. With Brief Observations on Visitatorial Power. Addressed to His Lordship (London, 1770).

14 J. Wentworth, A Complete System of Pleading, 10 vols. (London, 1797-9), vol. VI, 242-5. 
opinion regarding an appropriate interpretation of the College statute. ${ }^{15}$ The proceedings concern the publication of a treatise by William Frend entitled Peace and Union Recommended to the Associated Bodies of Republicans and Anti-Republicans. Although Harris was not called to appear in the Vice-Chancellor's Court, his opinion was used during the hearing. ${ }^{16}$

As a diocesan official, Harris was also acting widely as an administrator of different ecclesiastical legal matters. For example, as a commissary of Surrey, Harris was involved in the discussion regarding the dispute between the bishop of Winchester and the vicar general of the Province of Canterbury in issuing marriage licences (1765). ${ }^{17}$ At another point, Harris was presiding on behalf of the archbishop of Canterbury over proceedings regarding applications for medical licences. ${ }^{18}$

Further, like many other civilians at the time, Harris did not limit his practice to ecclesiastical law. He was also an advocate in the Admiralty, where he gained an important position and held the post of Admiralty Advocate between 1764 and $1782 .^{19}$

George Harris was professionally active until his death. The archives of Lambeth Palace possess documentation of a 1795 case pending in the Arches - the provincial court of the archbishop of Canterbury - wherein Harris was acting on behalf of the diocese of Winchester. ${ }^{20}$ Harris died only a few months later, on 19 April $1796 .{ }^{21}$ He left a last will in which he disposed of his huge wealth. ${ }^{22}$ He established several trusts, including two major ones on behalf of two London hospitals - one worth $£ 20,000$, the other $£ 15,000$. This is, in fact, not surprising, since Harris was involved in

15 W. Frend, An Account of the Proceedings in the University of Cambridge, Against William Frend, M.A. (Cambridge, 1793), xv-xvii.

16 Ibid., 226.

17 LPL, MS 1119, fos. 150-52.

18 LPL, VX IA/10/525/1-2 (2 June 1757); VX IA/10/527/1-2 (29 February 1768); VX IA/10/ 526/1-2 (10 December 1768).

19 J. Heydn and H. Ockerby, The Book of Dignities; Containing Lists of the Official Personages of the British Empire (London, 1890), 423. For Harris's admiralty cases see D. E. C. Yale, 'A Historical Note on the Jurisdiction of the Admiralty in Ireland', Irish Jurist, 3 (1968), 146-52, at 150, and D. Syrett, The Royal Navy in European Waters During the American Revolutionary War (Columbia, SC, 1998), 97-8.

${ }^{20}$ LPL, Arches Aa 90/2, 3, 5, 10, 2; Arches AAa 35a; Arches Bb 102/3; Arches D 1572; Arches E 45/91; Arches F 12 fos. 176-183.

21 There was only one obituary published, in The Annual Register for the Year 1796, 14-5. Besides, a short note regarding Harris's death was published in the German journal Intelligenzblatt der Allgemeinen Literatur-Zeitung, 76 (1800), 627.

22 London, The National Archives, PROB 11/1275/118. 
charity work during his lifetime. He was a member of the Corporations of the Sons of Clergy, which financially supported poor ecclesiastics and their families. ${ }^{23}$

\section{Translation of the Institutes: The Editions}

As pointed out earlier, George Harris became an important part of the science of Roman Civil law in England as the first translator of Justinian's Institutes. It is often believed that the first edition of his translation was published in 1756 by the London printers C. Bathurst and E. Withers. ${ }^{24}$ This assumption, however, is wrong. An anonymous translation of Justinian's first book of the Institutes, published in 1749, may in fact be the work of Harris. ${ }^{25}$ At first glance the translations are different. The 1749 translation seems to be closer to a paraphrase than a translation as such. One indication of Harris's authorship is an introductory essay entitled 'A Brief Account of the Rise and Progress of the Roman Law'. The essay seems to be an earlier version of another one titled in the same way, which was later published as the beginning of the 1756 edition. It is not likely that Harris borrowed the title and the text itself from someone else. The later edition is an enlarged, rethought story of the history of Roman law. Furthermore, a closer comparison of the 1749 and 1756 translations shows a certain level of similarities. It can be assumed that Harris, still a candidate to the doctoral degree in law in Oxford, published the 1749 translation as a result of his teaching experiences.

${ }^{23}$ His name can be found among the organisers of the Feast of the Sons of Clergy in 1768. See G. Mathew, A Sermon Preached at the Anniversary Meeting of the Stewards of the Sons of the Clergy (London, 1815), 15; The Royal Kalendar: Or, Complete and Correct Annual Register for England, Scotland, Ireland, and America for the Year 1796 (London, 1796), 207.

${ }^{24}$ G. Harris, D. Justiniani Institutionum Libri Quatuor. The Four Books of Justinian's Institution, Translated into English, With Notes (London, 1756). A year before Harris's translation, John Taylor published his well-known book Elements of Civil Law. Its second chapter contains exegetical analysis of Justinian's constitution Imperatoriam maiestatem, the one which promulgated the Institutes; see J. Taylor, Elements of Civil Law (Cambridge, 1755), 29-39.

${ }^{25}$ D. Justiniani Institutionum Liber Primus. The First Book of Justinian's Institutes, With English Version, and Notes (London, 1749). The translation was almost unnoticed. Only one note was released by the press soon after the translation's publishing: The Gentleman's Magazine, and Historical Chronicle, 19 (1749), 192. 
A further edition was published during his lifetime, namely the London edition of $1761 .^{26}$ Finally, in 1811 another edition was published in Oxford. ${ }^{27}$ All three editions of the entire Institutes were published without any changes. In 1814, a new version of the translation appeared, published without the original Latin text. ${ }^{28}$ It was also deprived of all the valuable notes provided by the civilian, while the introductory essay was much shortened.

A much more interesting history of Harris's translation started at about the same time in the United States. In 1812, Thomas Cooper released a collection of several Roman law-related texts jointly titled The Institutes of Justinian. With Notes. ${ }^{29}$ Cooper was an English-born lawyer and chemist who travelled to America, and at the time of the publication of the abovementioned set, he was a professor of chemistry at Carlisle College in Pennsylvania. Later, Cooper became a cofounder and second president of the University of South Carolina. ${ }^{30}$ Cooper's collection contained several other works in addition to the translation of the Institutes. The first of them was an English translation of the Twelve Tables. It was extrapolated from Nathaniel Hooke's voluminous work devoted to the history of ancient Rome. ${ }^{31}$ In addition, Cooper equipped his set of texts with an essay concerning the abbreviations used by the science of Roman law to indicate sources, as well as a list of famous Roman law scholars. Cooper's work gained much popularity in the United States. It was twice republished, first in $1841^{32}$ and again, in an enlarged version, in $1852 .^{33}$

Cooper's knowledge about Harris's translation may have been twofold. Cooper, like Harris, was an Oxonian. It is possible that he learnt

26 Institutions, Translated into English, With Notes, 2nd edn (London, 1761).

27 G. Harris, D. Justiniani Institutionum Libri Quatuor. The Four Books of Justinian's Institutions, Translated into English, With Notes, 3rd edn (Oxford, 1811).

28 Dr [G.] Harris, Institutions or Elements of Justinian. In Four Books. Translated from the Original Latin (London, 1814).

29 The Institutes of Justinian. With Notes, ed. T. Cooper (Philadelphia, PA, 1812).

30 T. Cooper, 'Cooper, Thomas (1759-1840)', in L. Stephen (ed.), Dictionary of National Biography, vol. XII (New York and London, 1887), 151-2. For a detailed biography of Cooper, see D. Malone, The Public Life of Thomas Cooper, 1783-1839 (New Haven, CT, London and Oxford, 1926).

31 N. Hooke, Roman History, From the Building of Rome to the Ruin of the Commonwealth, 4 th edn, 4 vols. (London, 1738-71), vol. II, 314-32.

32 T. Cooper, The Institutes of Justinian. With Notes, 2nd edn (New York, 1841).

33 T. Cooper, The Institutes of Justinian. With Notes. With Additional Notes and References, 3rd edn (New York, 1852). 
about the translation after matriculating at University College in 1779. He left the University, however, without any formal degree. He may also have learnt more about Justinian, his codification and Harris's work later, perhaps when he was admitted to the Inner Temple and became a barrister, or after his judicial appointment as a state judge in Pennsylvania.

The 1852 publication of Harris's translation was its last appearance. Interestingly, only a year later, Thomas Collett Sanders published the very first nineteenth-century rendition of the Institutes. In this way, he opened a new path for numerous new translations that were released variously in the United Kingdom, the United States and South Africa in the following one-hundred-and-fifty years. At the same time, Harris's translation began to fall into oblivion.

\section{Translation of the Institutes: Content}

Harris began his opus with an extensive dedicatory note addressed to Sir George Lee, then the dean of the Arches. ${ }^{34}$ In a typical panegyric manner, the civilian praised the merits of the judge for the development of English law as well as for his intellectual qualities. It would not be an exaggeration to say that Harris packed the note with all possible flattery. As an illustration, two passages can be quoted: 'and, as I have the honor to attend those courts, in which you so eminently preside, I may hope to avail myself of the many opportunities of instruction, which must continually offer themselves ${ }^{35}$ and 'the benefits, conferred by you, are not confined to individuals; your conduct as a Lord Commissioner of the Admiralty, and the satisfaction it gave the public, are sufficiently known'. ${ }^{36}$

It seems that Harris here had a pragmatic purpose. Not only was George Lee, as the dean of the Arches, the presiding member of the College of Advocates, but he was also the head of the court before which the civilian appeared. It should not be ruled out that Harris's actions were parts of his efforts to obtain a judgeship in the Arches. If this really was the case, it may be that these efforts were successful. The dedicatory note was signed by Harris on 25 February 1756. Less than three years later, in

\footnotetext{
34 W. P. Courtney, 'Lee, Sir George (1700-1758)', in S. Lee (ed.), Dictionary of National Biography, vol. XXXIII (New York and London, 1893), 353-6.

${ }^{35}$ Harris, D. Justiniani (1756), iv.

${ }^{36}$ Ibid., v.
} 
March 1759, the lawyer was already a surrogate-judge for the dean of the Prerogative Court of Canterbury. It is true that at the time the Arches had a new dean, Sir Edward Simpson, but Lee had died only a few months earlier.

After the dedication, Harris placed the advertisement, where he pointed out his main aims in preparing his translation. He emphasised that his work should be treated as an introduction to the Institutes' edition and commentary written by Arnold Vinnius. ${ }^{37}$ The second paragraph of the advertisement contains a short explanation regarding the notes added by Harris to the translation. He pointed out that the majority of them concern English law. He admitted also that they were not perfect but added that they should arouse the curiosity of a 'young reader'. He hoped that these notes could also rouse the desire of the readers to study more deeply their national law as well as the Civil law, described by Harris as 'the Master-work of human policy'. ${ }^{38}$

Finally, the introductory part is crowned with the already-mentioned 'A Brief Account of the Rise and Progress of the Roman Law' ${ }^{39}$ Starting from the earliest stages of Roman legal history, Harris presented first the semi-legendary stories of the legislative activity of Romulus, a gathering of the leges regiae by Sextus Papirius and finally the exile of Tarquinius Priscus from Rome. In the opinion of Harris, the subsequent events that led to the creation of the republic were the times of 'great incertainity in respect to law'. Arbitrary decisions of the magistrates brought widespread discontent among the people. As a consequence, the patricians succumbed to the plebeians and decided to appoint the ten men - decemviri - who would eventually propose a project to enact a law that would be partially based on Greek laws and partially on previous Roman laws. Next, Harris presented the circumstances that led to the appointment of another decemviri committee and to shape the final version of what would be known as the law of the Twelve Tables. ${ }^{40}$

${ }^{37}$ Harris was referring to Vinnius's In quatuor libros Institutionum imperialium commentarius academicus \& forensis, which was published first in the Netherlands in 1646. Until the nineteenth century the work enjoyed great popularity. The total number of the editions reached 154. See L. Beck Varela, 'Vinnius: Commentary on the Institutes', in S. Dauchy, G. Martyn, A. Musson, H. Pihlajamäki, and A. Wijffels (eds.), The Formation and Transmission of Western Legal Culture: 150 Books that Made the Law in the Age of Printing (Cham, 2016), 197-200, at 198.

${ }^{38}$ Harris, D. Justiniani (1756), viii.

39 Ibid., ix-xv.

${ }^{40}$ Ibid., ix-x. 
The story told by Harris is focused on the republican period. He noticed that shortly after the enactment of the lex duodecim tabularum, its provisions started to be changed due to their severity. In his opinion, the Senate was primarily responsible for these changes, as well as the plebeians who voted during their assemblies. It is curious, from a modern point of view, that he did not mention the role played by the far more important legislative body of the republican period, the popular assembly, and their statutes (leges). Instead, Harris pointed out the important role played by the learned jurists, by what he calls 'auctoritas prudentum'. ${ }^{41}$ Harris went on to state that after the promulgation of the law of the Twelve Tables, the Roman system of actiones was constituted. At first, they were unknown to the public until Flavius made them public. Shortly thereafter, Sextus Aelius introduced a newer, much improved system of the legal actions. ${ }^{42}$

Harris then suddenly changed the course of his arguments to focus on the pretorian edict. He explained that although the edict lost its authority after the one-year term of office of the pretor, nevertheless 'many of them were so truly valuable for their justice and equity, that they have been perpetuated as laws. ${ }^{43}$

After these extended deliberations regarding the republican period, Harris dealt with the principate in just one paragraph. He declared that after the 're-establishment of monarchy' by Augustus, the Roman law gained new types of sources - the imperial constitutions and the responses of the lawyers. ${ }^{44}$ The details regarding their issuing were, however, not interesting to him. Instead, he skipped about three-hundred years and proclaimed that at that time the number of the imperial constitutions was so great that it was necessary to codify them. He listed the names of the lawyers Gregorius and Hermogenes ( private collections of the constitutions during the reign of the emperor Constantine. Next, he emphasised, an official collection was promulgated on the command of Emperor Theodosius. Harris summed up this part of 'A Brief Account' by saying that all the foregoing attempts to fix the state of imperial legislation were imperfect. Due to this, the great work of Justinian's codification was necessary. ${ }^{45}$

41 Ibid., ix.

42 Ibid.

43 Ibid., xii.

44 Ibid.

45 Ibid. 
In the following paragraphs, Harris presented the stages of the works of codification carried out by the forces appointed by the emperor. $\mathrm{He}$ mentioned that the laws created on behalf of the emperor should be unchangeable and that they should not be summarised or excerpted. ${ }^{46}$ In a separate paragraph, Harris pointed out that Justinian had continued his legislative efforts by issuing novels and edicts which were written in Greek rather than Latin. He explained that it was a consequence of the greater popularity of Greek language in the Eastern Empire. He finished these deliberations by mentioning the release of the Basilica. ${ }^{47}$

Harris devoted the last part of 'A Brief Account' to the problem of later knowledge of the codification in Western Europe. He explained that it was not commonly known in the former Western Empire, and after the Lombard invasion it was nearly forgotten. Both Code and Pandects were missing until their rediscovery in the twelfth century, respectively in Ravenna and Amalfi. Since that time, however, they have been a subject of constant studies. ${ }^{48}$

There are no doubts that the history of Roman law and its sources presented by Harris is disputable, especially when compared with twenty-first-century knowledge of Roman legal science. Harris's knowledge, especially about the archaic and pre-classical Roman law, is rather simplified and based more on conjectures and legends than scientific arrangements. Other matters, like the rediscovery of the Digest in Amalfi were still unverified. It is important to remember, however, that 'A Brief Account' was only a short introduction and should precede further reading of Vinnius's commentary.

After 'A Brief Account', the main section of Harris's book starts: the translation equipped with numerous notes. His pattern is as follows: he first gives the original Latin text, followed by the English translation typed in italics. Where he believed it was necessary, he included a short commentary and the explanation of the pivotal terms at the end.

One of the characteristic features of Harris's translation was his inclusion of a reference to the parallel segments in other parts of Justinian's codification at the start of every title in the Institutes. For example, beneath the name of the first title of the first book of the Institutes (De iustitia et iure) Harris indicated the designation 'D. 1 T. 1' that redirects the reader to the first title of the first book of Justinian's Digest, which

\footnotetext{
${ }^{46}$ Ibid., xii-xiv.

47 Ibid., xiv.

${ }^{48}$ Ibid., Xv.
} 
bears the same name. In another place, beneath the eighteenth title of the second book of the Institutes (De inofficioso testamento) the translator indicated the parallel places both in the Digest ${ }^{49}$ and the Code.$^{50}$ Such practice was characteristic for English civilian literature in the eighteenth century. It can be observed in various places throughout the century. Francis Dickins, the Regius Professor of Civil Law in Cambridge (1714-55) used it, for example, in his lecture notes. ${ }^{51}$ In the 1770 s the same method was exploited by Samuel Hallifax in his textbook. ${ }^{52}$

Another characteristic of Harris's work was the addition of informal subtitles clarifying the content of the following segment of the Institutes. A good example is the already-mentioned title De inofficioso testamento. It was divided into the following subtitles: Ratio huius querelae (I. 2, 18, pr.); Qui de inofficioso agunt (I. 2, 18, 1); Qui alio iure veniunt, de inofficioso non agunt (I. 2, 18, 2); De eo, cui testator aliquid reliquit (I. 2, 18, 3); Si tutor, cui nihil a patre relictum, pupilli nomine legatum acceperit (I. 2, 18, 4); Si de inofficioso nomine pupilli agens succubuerit (I. 2, 18, 5); De quarta legitima partis (I. 2, 18, 6-7). Although the addition was unique in comparison with other civilian works of the epoch, it was not Harris's independent idea. The names of the subtitles were borrowed from Vinnius's commentary.

The publication of the English translation of Justinian's Institutes was a very important event in the history of the English science of Roman Civil law. A crucial component of that translation was the notes. In fact, they were arguably the most significant element of the translation. Close analysis of them shows that Harris was a very well-read independent scholar who knew both older and more recent legal literature well. His reading was not restricted to Civil law. On the contrary, Harris also reveals extensive knowledge of the English legal system. It is noteworthy that the works to which Harris referred very often represented other disciplines and are a good manifestation of the lawyer's comprehensive knowledge.

These legal sources are quoted by Harris on many different occasions. He had an extensive orientation in all parts of Justinian's codification. In many notes it is possible to find direct references to parallel passages of the Digest, Code and Novels. Quite often he based his argumentation also

49 D. 5, 2 (De inofficioso testamento).

50 C. 3, 28 (De inofficioso testamento).

51 Cambridge, Trinity Hall, Old Library, MS 31.

52 S. Hallifax, An Analysis of the Roman Civil Law, 2nd edn (Cambridge, 1775). 
on Theophilus's Paraphrase. ${ }^{53}$ The Theodosian Code, by contrast, was used infrequently. Harris also quoted non-legal sources. Besides the Cicero orations, ${ }^{54}$ he also referred to Tacitus's Annales, ${ }^{55}$ Suetonius ${ }^{56}$ and Aulus Gellius. ${ }^{57}$ Among the Greek authors, he used the works of Dionysius of Halicarnassus, ${ }^{58}$ Herodotus, ${ }^{59}$ Plutarch $^{60}$ and the Homeric epics. $^{61}$

As for the scholarly works, Harris referred to a great number of Roman Civil law authors who represent different traditions. It is possible to find in the notes citation of the following authors: Bartolus, ${ }^{62}$ Philibert Bugnyon, ${ }^{63}$ Diego de Covarrubias y Leyva, ${ }^{64}$ Cujacius (Cujas), ${ }^{65}$ Jean Domat (quoted both in the original version ${ }^{66}$ as well as in the English translation by William Strahan), ${ }^{67}$ Jean Doujat ${ }^{68}$, Claude-Joseph de Ferrière, ${ }^{69}$ Simon van Groenewegen van der Made, ${ }^{70}$ Johann Friedrich Gronovius, ${ }^{71}$ Grotius, ${ }^{72}$ Heineccius, ${ }^{73}$ Joachim Hoppe, ${ }^{74}$ François Hotman, ${ }^{75}$ Gilles Ménage, ${ }^{76}$ Joachim Mynsinger von Frundeck, ${ }^{77}$

${ }^{53}$ In one place Harris pointed out that he worked on the Paraphrase edition by Willem Otto Reitz published in The Hague in 1751.

${ }^{54}$ Harris, D. Justiniani (1756), book 1, 16, 70; book 4, 39.

${ }^{55}$ Ibid., book 1, 38; book 4, 55 .

56 Ibid., book 1, 38, 50, 66; book 4, 55 .

57 Ibid., book 4, 3, 25.

58 Ibid., book 1, 66 .

59 Ibid., book 1, 67.

${ }^{60}$ Ibid., book 1, 32 .

${ }^{61}$ Ibid., book 3, 76-77.

62 Ibid., book 1, 43 .

${ }^{63}$ Ibid., book 4, 81 .

${ }^{64}$ Ibid., book 4, 4 .

65 Ibid., book 1, 13; book 2, 91; book 3, 43; book 4, 60 .

${ }^{66}$ Ibid., book 2, 26, 44, 47, 86.

67 Ibid., book 1, 14; book 2, 26, 44, 47, 86.

${ }^{68}$ Ibid., book 3, 6 .

${ }^{69}$ Ibid., book 1, 64; book 2, 10, 70, 91; book 3, 69 .

${ }^{70}$ Ibid., book 3, 40.

${ }^{71}$ Ibid., book 1, 9; book 2, 120; book 4, 81 .

${ }^{72}$ Ibid., book 2, 16; book 4, 5 .

${ }^{73}$ Ibid., book 1, 3, 68; book 2, 21; book 3, 18, 50, 60; book 4, 15, 26, 39, 55 .

${ }^{74}$ Ibid., book 1, 9.

75 Ibid., book 4, 60 .

76 Ibid., book 4, 76 .

77 Ibid., book 1, 7, 40, 43; book 2, 70; book 3, 12, 19, 27, 40-41, 56. 
Matthew Wesenbeck ${ }^{78}$ and, naturally, Arnold Vinnius. ${ }^{79}$ In addition to these Continental scholars, Harris referred to only three English civilians, all of whom were living in the eighteenth century, namely Robert Eden, ${ }^{80}$ John Taylor ${ }^{81}$ and Thomas Wood. ${ }^{82}$

A separate group, much more interesting than the English civilians, is made up of writers on English law, whom he used extensively. This is a rather surprising occurrence, especially given that Harris had never been trained in Common law. It can be assumed, however, that he was quite well self-educated in this field of knowledge. Besides the oldest English legal treatises, i.e. Glanvill ${ }^{83}$ and Bracton, ${ }^{84}$ Harris referred also to another medieval text - Britton. ${ }^{85}$ The lawyers of later epochs cited by Harris are: Matthew Bacon, ${ }^{86}$ Thomas Blount ${ }^{87}$ Edward Coke, ${ }^{88}$ John Cowell, ${ }^{89}$ Anthony Fitzherbert, ${ }^{90}$ John Fortescue, ${ }^{91}$ Matthew Hale, ${ }^{92}$ William Hawkins, ${ }^{93}$ Thomas Littleton, ${ }^{94}$ John Rastell, ${ }^{95}$ Thomas Smith, ${ }^{96}$ Christopher St German ${ }^{97}$ and Thomas Wood. ${ }^{98}$

Harris was also keen to refer to English ecclesiastical lawyers, including Edmund Gibson, ${ }^{99}$ John Godolphin ${ }^{100}$ and Henry Swinburne. ${ }^{101}$

78 Ibid., book 3, 27.

79 Ibid., book 1, 20, 32, 33, 35, 38, 40, 66, 68; book 2, 58, 79, 81, 100, 119, 120; book 3, 3, 10 , $12,13,20,21,25,27,35,36,41,44,61,64,65,66,78,80,88,89$; book 4, 26, 30, 33, 81, 92.

${ }^{80}$ Ibid., book 1, 9, 66 .

${ }^{81}$ Ibid., book 3, 29.

82 Ibid., book 2, 20, 23, 25.

${ }^{83}$ Ibid., book 2, 16; book 4, 31 .

${ }^{84}$ Ibid., book 1, 25, 35; book 2, 16; book 4, 31, 36, 74, 84 .

${ }^{85}$ Ibid., book 4, 74 .

${ }^{86}$ Ibid., book 1, 61; book 2, 15; book 3, 16, 71; book 4, 9, 19, 21, 30, 31, 34 .

87 Ibid., book 4, 31 .

${ }^{88}$ Ibid., book 1, 35, 50; book 2, 15, 16, 19, 27; book 3, 24; book 4, 1, 4, 66, 87, 88, 89, 92.

${ }^{89}$ Ibid., book 1, 65; book 2, 19, 25, 29, 46, 69, 79; book 3, 40, 61; book 4, 15, 34, 40, 42, 51, 56,74 .

90 Ibid., book 4, 40, 85 .

91 Ibid., book 1, 15, 50.

92 Ibid., book 1, 8; book 4, 4, 5, 8, 9, 12, 13, 16, 56, 87.

93 Ibid., book 1, 25; book 3, 86; book 4, 14, 16, 56, 87.

94 Ibid., book 1, 15, 27, 34, 43, 44, 47, 48; book 2, 29; book 3, 65; book 4, 30, 33, 61, 66, 84 .

95 Ibid., book 3, 24; book 4, 84, 85 .

96 Ibid., book 1, 12.

97 Ibid., book 4, 51 .

98 Ibid., book 2, 19, 29; book 3, 82; book 4, 7.

99 Ibid., book 1, 25.

100 Ibid., book 3, 24.

101 Ibid., book 1, 55; book 2, 44, 47, 49, 54, 56, 57, 58, 59, 68, 86, 87, 109, 119; book 3, 24. 
In addition, in one of the notes, Harris referred to a work entitled Ordo iudiciorum ${ }^{102}$ but did not insert the name of the author. The context of Harris's statement, however, suggests that he was referring to the work published in 1728 by Thomas Oughton. ${ }^{103}$ Pre-Reformation literature was not exploited by Harris, except that he referred three times to Gregory IX's Liber extra. ${ }^{104}$ The 'ecclesiastical' context was strengthened by Harris referring to passages from the Bible as well as the theological literature. It is interesting that among that last type of references it is possible to find a citation of the Catholic theologian, Peter Faber, a Jesuit priest and the disciple of Ignatius of Loyola. ${ }^{105}$

As to English law, it has to be emphasised that Harris devoted much of his attention to the problems of legislation and court practice. ${ }^{106}$ This last feature of the translation is especially fascinating. The oldest law reports quoted by Harris date back to the sixteenth century. These are the reports of the judge Sir James Dyer, ${ }^{107}$ those known as Keilway's Reports ${ }^{108}$ as well as those of the lawyer Edmund Plowden. ${ }^{109}$ From the late sixteenth and early seventeenth centuries come another three law reports: Sir Edmund Anderson's, ${ }^{10}$ Sir Edward Coke's ${ }^{111}$ and Sir George Croke's. ${ }^{112}$ The seventeenth century is represented by the reports by Thomas Hardres, ${ }^{113}$ Thomas Siderfin ${ }^{114}$ and John Vaughan ${ }^{115}$ and the collection known as Levine's King's Bench and Common Pleas Reports $1660-1697 .{ }^{116}$ The turn of the seventeenth and eighteenth century is represented by the reports series Modern Reports ${ }^{17}$ and the reports

102 Ibid., book 4, 80.

103 See e.g. Ł. J. Korporowicz, 'Was the Roman Catholic Canon Law Studied in Eighteenth Century England?', Studia Prawno-Ekonomiczne, 108 (2018), 83-102, at 96-7.

${ }^{104}$ Harris, D. Justiniani (1756), book 2, 46; book 4, 80, 91.

105 Ibid., book 3, 27.

${ }^{106}$ Harris referred both to pre-1066 and post-1066 legislation. The Anglo-Saxon legislation was known to him through the work by D. Wilkins: Leges Anglo-Saxonicae, Ecclesiasticae \& Civilis (London, 1721).

107 Harris, D. Justiniani (1756), book 1, 12; book 2, 57; book 4, 31.

108 Ibid., book 1, 25.

109 Ibid., book 4, 5 .

110 Ibid., book 2, 57.

111 Ibid., book 1, 44, 61; book 2, 19; book 4, 16, 22, 23, 92.

112 Ibid., book 1, 57, 58.

113 Ibid., book 1, 71 .

114 Ibid., book 1, 71; book 2, 57.

115 Ibid., book 1, 30, 32, 44, 61, 71.

116 Ibid., book 1, 55; book 4, 92 .

117 Ibid., book 2, 87; book 3, 21. 
collected by William Salkeld, ${ }^{118}$ whilst the eighteenth century is witnessed by the reports authored by Sir Jeffrey Gilbert, ${ }^{119}$ Lord Raymond $^{120}$ and Sir John Strange. ${ }^{121}$ The activity of the Chancery is attested by Harris through the quotation of four reports series: an anonymous A General Abridgement of Cases in Equity, Argued and Adjudged in the High Court of Chancery etc., ${ }^{122}$ the Chancery Cases ${ }^{123}$ and the Chancery Reports, ${ }^{124}$ as well as the reports of Thomas Vernon. ${ }^{125}$ The ecclesiastical judgments are quoted only once, when Harris referred to the reports collected by Edward Stillingfeet. ${ }^{126}$

Quite unique are the references to the experience of Scottish institutional writers - Sir George Mackenzie ${ }^{127}$ and Lord Stair. ${ }^{128}$ In both cases Harris referred to their Institutions. Also, in one place, it is possible to find a mention of Norman customs of the Channel Islands. ${ }^{129}$

Obviously, Harris was also using some secondary, auxiliary literature. Among these works, it is worth mentioning the historical pieces Basil Kennett's Antiquities of Rome ${ }^{130}$ and John Potter's Archaeologia Greca or the Antiquities of Greece. ${ }^{131}$ Besides, Harris was using philosophical works, like Tetrachordon by John Milton ${ }^{132}$ and Montesquieu's De l'esprit des lois. ${ }^{133}$ Among the dictionaries can be mentioned Thesaurus linguae latinae by Robert Estienne $\mathrm{e}^{134}$ and Thesaurus eruditionis scholasticae by Basil Faber. ${ }^{135}$

Following the translation of the Institutes, Harris added a single supplement to his work. It was an English translation of the Novel 118, decreed by Justinian in 543 . The imperial constitution was part of the

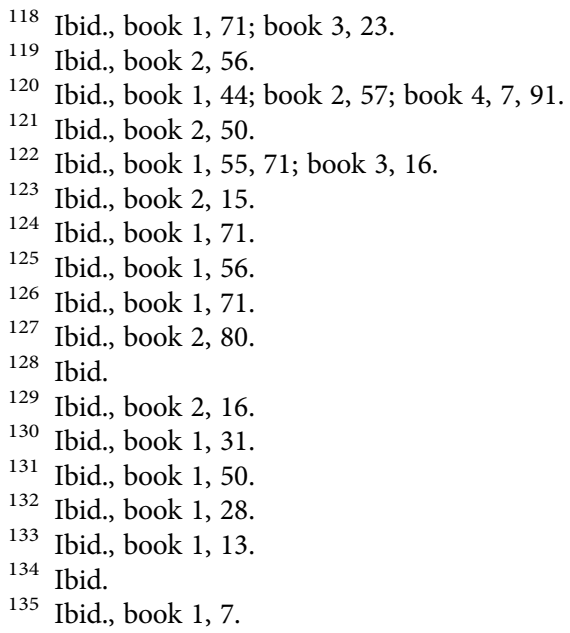


famous changes that the emperor introduced in the field of the intestate succession. The reason for its attachment to the translation of the Institutes is not clear, as Harris did not explain his action in this regard. It seems natural, though, that the translation could have been dictated by practical reasons. After all, ecclesiastical courts - the domain of the civilians' activity - were mainly preoccupied with testamentary inheritance cases. The Novel and its translation cover a little over ten pages. The text was presented in three ways. First, Harris presented the Greek version of the constitution. Second, the Latin translation of the constitution was added. Finally, beneath these two versions, an English translation was included.

Just as with the Institutes, the lawyer equipped the Novel with extensive commentaries. The apparatus is varied again. Among the civilian works it is possible to find the two pieces already mentioned before written by Domat ${ }^{136}$ and Ferrière. ${ }^{137}$ In addition, Harris also used two other civilian treatises authored by Petrus Gudelinus (Pierre Goudelin) ${ }^{138}$ and Johannes Voet. ${ }^{139}$ English law is again represented by Glanvill, ${ }^{140}$ Littleton $^{141}$ and Coke, ${ }^{142}$ and in addition by the work on criminal law written by Sir Michael Foster. ${ }^{143}$ Finally, the law reports were used by Harris. Only the reports of Lord Raymond ${ }^{144}$ were reused. In addition, another three were used by Harris for the very first time: the reports prepared by Sir John Holt, ${ }^{145}$ Sir Bartholomew Shower ${ }^{146}$ and William Peere Williams. ${ }^{147}$

What were the origins of such a wealth of literature? The translation was published in 1756. Even, if it is assumed that this project was initiated by Harris while still at Oxford, the 1749 edition of the translation does not reveal much about Harris's interest in constructing elaborate notes. It seems plausible that the notes were mostly already written after Harris's graduation, while he was a member of the College of

\footnotetext{
136 Ibid., Nov., 5, 11.

137 Ibid., Nov., 5.

138 Ibid.

139 Ibid., Nov., 6.

140 Ibid., Nov., 5.

141 Ibid.

142 Ibid., Nov., 10.

143 Ibid., Nov., 5.

144 Ibid., Nov., 3.

145 Ibid.

146 Ibid., Nov., 11.

147 Ibid., Nov., 3, 5.
} 
Advocates. Besides a private library which was definitely continually expanded by Harris, ${ }^{148}$ it is most likely that his main supplying source was the library of the Doctors' Commons. This conclusion can be partially confirmed by juxtaposing the list of works used by Harris with the library catalogue of Doctors' Commons published in 1818. ${ }^{149}$ Although not all the works to which he referred can be found in the catalogue, many of them were in the College's possession. While he was living in London, it is possible that Harris also had access to Lambeth Palace Library as well as the libraries of the Inns of Court. Finally, it is plausible that he used bishops' or cathedrals' libraries while he was travelling around the country to fulfil his professional duties.

\section{Assessments of Harris's Translation}

The first English translation of the entirety of Justinian's Institutes predictably met with some response from the scholarly and literary worlds. Harris's translation became a subject of three reviews. The first one appeared in July 1756 in The Monthly Review. ${ }^{150}$ The time of preparing the review was exceptionally short given that Harris dated his dedication note on 25 February $1756 .{ }^{151}$ The book had to have been published in March or April the same year. The review was anonymous, signing as 'W.'. In the introduction, the reviewer emphasised his admiration of Roman culture, warfare, policy and government, concluding that nothing illustrates Roman greatness better than its legal order. He believed that the importance of Roman law had much exceeded Rome's military achievements. ${ }^{152}$ In this way, 'W.' started to present the content of Harris's work. He valued 'A Brief Account' highly, stating that the introductory essay was 'very authentic, improving, and agreeable'. ${ }^{153}$

\footnotetext{
${ }^{148}$ Harris's name frequently appears in the subscribers' lists of many books, e.g. T. Richards (ed.), Antiquae linguae Britannicae thesaurus (Bristol, 1753), xxix; J. Thorpe and J. Thorpe, Registrum Roffense: Or a Collection of Antient Records, Charters, and Instruments of Divers Kinds (London, 1769), 8.

149 Catalogue of the Books in the Library of the College of Advocates in Doctors' Commons (London, 1818).

150 Monthly Review, 15 (1756), 1-18.

151 Harris, D. Justiniani (1756), vii.

152 Monthly Review, 15 (1756), 2.

153 Ibid., 3.
} 
The reviewer gave several quotations taken from Harris's work, ${ }^{154}$ which he then commended, and indicated that the translator coped well with the complexities of the Latin language and 'elucidated with equal propriety and clearness. ${ }^{155} \mathrm{He}$ also expressed his appreciation for all the notes added by Harris to his translation. 'W.' believed that they served as an expression of particular ideas and were added 'without the vain frippery of superfluous learning'. The notes themselves were called by 'W.' 'instructive and judicious'. ${ }^{156}$ In a further part of the review, 'W.' quoted over a dozen exemplary notes, ${ }^{157}$ and he emphasised their comparative character. In the closing of the review, it is stated of Harris's book: 'a work peculiarly adapted for the improvement of the young Student in Law, for whose service it seems principally to have been intended; but worthy also the perusal of every Gentlemen, who would form a just notion of the civil policy of the Romans, and obtain, at the same time, a comparative view of our own'. ${ }^{158}$

About a year later, in April 1757, a second review was published in Leipzig. ${ }^{159}$ German interest in an English translation may be at first sight surprising, but in fact it shows the importance of translating Justinian's Institutes into English. In addition, one of the central arguments in favour of the edition, according to the reviewer, was its discussion of the comparative character of Roman and English legal institutions. In his opinion, the translation undertaken by Herr Harris would benefit both Englishmen and foreigners, who would like to learn more about the barely known, but extensive English legislation. ${ }^{160}$ It can be mentioned that the reviewer's knowledge about the condition of English civilian literature had to be relatively good. At the beginning of his review he noticed that Harris's edition was released only a year after Taylor's exegetical analysis of the imperial constitution Imperatoriam maiestatem. ${ }^{161}$

The last review was published in February 1761 in The Critical Review, or Annales of Literature. ${ }^{162}$ The late date of publication of the review was

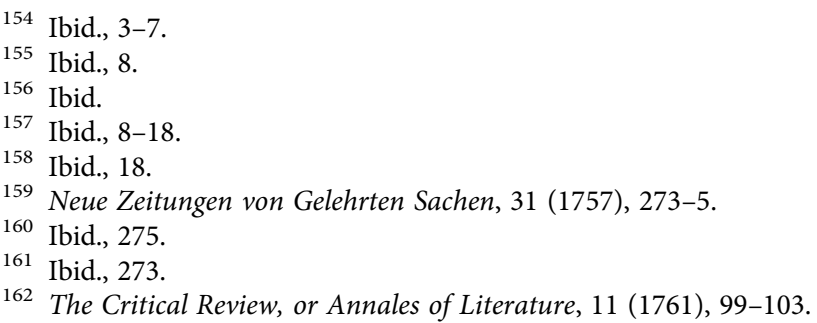


explained at once. The first edition of the translation preceded the creation of The Critical Review. For this reason, an opportunity to write a review was the publishing of the second edition of Harris's work. Almost the entire first two pages of the review served as a presentation of the significance of Justinian's codification for Roman law, as well as its aftermath in Western Europe. It can be assumed that the reviewer used as a template for his own considerations a seventeenth-century book written by Sir Arthur Duck - De usu et authoritate Iuris civilis Romanorum in dominiis principum Christianorum. The reviewer briefly described different European legal systems and their use of Roman law (though he omitted Central and Eastern Europe, which were included by Duck in his book).

The reviewer proclaimed that 'the public is greatly obliged to the learned translator, for clearing the channels to the foundation of justice, before obstructed by the difficulty and ambiguity which always attends a dead language'. ${ }^{163}$ The translation was evaluated as 'just and not inelegant', and the notes were once more highly praised. Again, the reviewer emphasised the importance of Harris's comparisons between Common law and Civil law. Still, according to the evaluator, some notes (especially those related to the law of nations and natural law) were inaccurate. ${ }^{164}$ As an example, the reviewer pointed out Harris's notes regarding the legal status of black slaves coming from colonies to the metropole. Nevertheless, the reviewer resumed his assessment by saying that 'our author is a free, sensible, and judicious translator. ${ }^{165}$

\section{Conclusions}

The richness of sources, literature and law reports exploited by Harris makes a big impression on the reader. It can be safely considered that the method that he used far transcended the standards of typical mideighteenth-century literature, and definitely the standards of an author who was not involved in academia. A bibliography of all the works used by Harris reaches more than ninety items. These were used not to write a coherent monograph, but rather to enrich the translation with learned notes.

\footnotetext{
163 Ibid., 100.

164 Ibid.

165 Ibid., 103.
} 
The unique character of the work is also concealed in Harris's aim. As he pointed out in the advertisement of his book, his commentaries were not designed as an explanation of the Roman Civil law terms. Instead, Harris wanted to arouse curiosity about English law. The goal was achieved. The English aspect of the notes is unanimously emphasised by the reviewers of Harris's work. The variety of legal treatises used by him on this subject is astonishing. Far more important, however, is Harris's habit of indicating passages from the law reports as an answer to problems discussed. In the mid-eighteenth century, the doctrine of precedent was not fully accepted among lawyers. Though they respected and referred eagerly to earlier judicial decisions, these decisions were not irrebuttable. The judicial activism of Lord Mansfield finalised the process of rooting the doctrine of precedent in Common law. ${ }^{166}$ When the civilian refers to the law reports so often in his work, it can be treated as an illustration of changes in the judicial practice. ${ }^{167}$ It is odd that Harris utilises so little his ecclesiastical experience. Ecclesiastical law appears in his notes rather rarely. Nonetheless, it is no exaggeration to say that Harris's notes are truly comparative in character.

166 J. Oldham, 'Lord Mansfield, Stare decisis, and the Ratio decidendi 1756 to 1788 ', in W. H. Bryson and S. Dauchy (eds.), Ratio decidendi: Guiding Principles of Judicial Decisions, vol. I: Case Law (Berlin, 2006), vol. I, 137-50, at 138-44.

167 In fact, Lord Mansfield was appointed as a chief justice of the King's Bench a few months after Harris's translation was published. 